\title{
The Investigation of Virginiamycin-Added Fungal Fermentation on the Size and Immunoreactivity of Heat-Sensitive Soy Protein
}

\author{
Liyan Chen, ${ }^{1}$ Praveen V. Vadlani, ${ }^{1}$ Ronald L. Madl, ${ }^{1}$ Weiqun Wang, \\ Yongcheng Shi, ${ }^{1}$ and William R. Gibbons ${ }^{3}$ \\ ${ }^{1}$ Grain Science and Industry Department, Kansas State University, Manhattan, KS 66506, USA \\ ${ }^{2}$ Human Nutrition Department, Kansas State University, Manhattan, KS 66506, USA \\ ${ }^{3}$ Biology \& Microbiology Department, South Dakota State University, Brookings, SD 57006, USA \\ Correspondence should be addressed to Liyan Chen; liyanchen01@gmail.com
}

Received 21 January 2015; Accepted 15 April 2015

Academic Editor: Long Yu

Copyright ( $\odot 2015$ Liyan Chen et al. This is an open access article distributed under the Creative Commons Attribution License, which permits unrestricted use, distribution, and reproduction in any medium, provided the original work is properly cited.

The usage of soy protein for young monogastric animals is restricted due to potential allergens and high molecular weight. The investigation of fungi fermentation effect on soy protein has been interrupted by substrate sterilization. Virginiamycin at $0.05 \%$ was added together with Aspergillus oryzae for solid state fermentation (SSF) in unsterilized soy meal (SM). When compared to A. oryzae SSF alone, virginiamycin did not cause the interference of fungal fermentation but elucidated the protein degradation. SDS-PAGE results showed that both $\alpha$ and $\alpha^{\prime}$ subunits of $\beta$-conglycinin were degraded significantly. In addition, western blot results showed that the immunoreactive signals of soy protein were considerably reduced in virginiamycin-added fermentation with unsterilized SM. Furthermore, fungal fermentation increased total protein and essential amino acid contents, suggesting the value enhancement of SM products. Taken together, this study demonstrated for the first time that virginiamycin could help investigate fermentation effect on heat-sensitive soy protein. Fermented SM has several potential applications in feed industry.

\section{Introduction}

Soy meal (SM) is the main protein source for monogastric animals in the United States [1]. But its inclusion in newly weaned pigs is limited because of some antinutritional factors and antigenic soy proteins causing hypersensitivity [2]. To date, 34 soybean proteins have been identified as allergens [3]. All three parts of the $\beta$-conglycinin, both acidic and basic subunits of glycinin and P34, have been identified as main allergens for young pigs [3-5]. Some studies indicate that incorporation of antigenic soy proteins such as pure glycinin or $\beta$-conglycinin to the diet leads to a reduced weight gain and feed efficiency as well as an increased incidence of diarrhea in pigs [4]. Furthermore, SM contains large molecular size proteins that are difficult for digestion, because many digestion enzymes such as pepsin and trypsin cannot perform their entire function until 3 weeks of age in piglets [4].

Fermentation has been applied to improve soy protein immunity and degrade protein molecular size. Song et al. [6] found that natural fermentation, Saccharomyces cerevisiae, and Bacillus lactis fermentation of SM reduced in $80 \%$, $77 \%$, and $77 \%$ immune response when using $97.5 \mathrm{kUA} / 1$ human plasma, respectively. Amnuaycheewa and de Mejia [7] analyzed the profilin in fermented soy products. The reduction in profilin in natto fermented by Bacillus natto was $12.8 \%$ to $35.4 \%$ and for soy paste $12.8 \%$ to $46.3 \%$, in comparison to soy flour. But as for the fungal fermentation effect on SM immunity, research is limited. Frias et al. [5] found that Aspergillus oryzae or Rhizopus oryzae solid state fermentation produced a reduction of immunoreactivity of $68 \%$ or $66 \%$ of soy meal, respectively. But both fermentations used $121^{\circ} \mathrm{C} 15 \mathrm{~min}$ sterilization before and after. Since high heat could denature protein [8] and reduce its immunity [3], it could not elucidate that the deduction of immunity was caused by fermentation. Fungal solid state fermentation of SM has been applied to enhance the nutritional value of SM as monogastric animals' feed [9]. Animal test has already found that feeding fermented SM (FSM) could decrease the immune 
response to soy protein in piglets [10]. However, enzymes with different origins have different hydrolytic effect [11]. There is a need to find the proper way to investigate whether and how a specific fungus solid state fermentation affects soy protein immunoreactivity.

Virginiamycin is one of the common antibiotics used in feed industry [12]. Also it has been used in ethanol production to prevent contamination during fermentation [13]. In our research, we applied virginiamycin to inhibit bacteria growth during $A$. oryzae solid state fermentation in unsterilized SMV. In addition, we demonstrated a method to perform fermentation under unsterilized condition and therefore distinctly investigated molecular degradation and immunoreactivity reduction of heat-sensitive soy protein.

\section{Materials and Methods}

2.1. Microbial Culture. Lyophilized cultures of A. oryzae (ATCC 9362) were obtained from the American Type Culture Collection (ATCC, Manassas, VA, USA), revived in potato dextrose broth twice. After revival, culture was inoculated on potato dextrose (PDA) slant, incubated at $30^{\circ} \mathrm{C}$ for 7 days, and later stored at $4^{\circ} \mathrm{C}$ for short term preservation. For routine experiments, spore solution was used. Spores were collected from the slants by gently washing with $0.1 \%$ Tween 80 to obtain spore suspension of around $10^{7}$ spores $/ \mathrm{mL}$. Additionally, spores were suspended in $15 \%$ glycerol and stored at $-80^{\circ} \mathrm{C}$ in $1 \mathrm{~mL}$ aliquots for long term preservation.

2.2. Substrate Preparation and Fermentation. SM was procured from ADM Alliance Nutrition (Abilene, KS). Solid state fermentation was carried out with three different kinds of substrates, which were original SM with virginiamycin, SM autoclaved at $100^{\circ} \mathrm{C}$ for $30 \mathrm{~min}$ (SM100C), and SM autoclaved at $121^{\circ} \mathrm{C}$ for $15 \mathrm{~min}$ (SM121C). Their corresponding fermented products were characterized as SMV, SM100, and SM121. For SMV, virginiamycin was added at a ratio of $0.05 \%$ dry matter base of SM, based on the results of our preliminary experiment. Four milliliters of $A$. oryzae spore solution containing $10^{7}$ spores $/ \mathrm{mL}$ was inoculated into $20 \mathrm{~g}$ substrate. Moisture was adjusted before autoclave. Moisture contributed by inoculation was considered. And final moisture was $50 \%$. The flasks were incubated at $35^{\circ} \mathrm{C}$ for $36 \mathrm{hr}$. The fermented samples were then lyophilized and used for analysis.

2.3. Soy Protein Sample Preparation. Lyophilized FSM was milled with mortar and pestle to flour. SM flour was dispersed in distilled water at a ratio of $1: 10$. The mixture $\mathrm{pH}$ was adjusted to $\mathrm{pH} 8.2$ by using $2 \mathrm{~N} \mathrm{NaOH}$. After 2 hr of shaking at room temperature, the mixture was centrifuged at 5,000 rcf at $4^{\circ} \mathrm{C}$ to remove insoluble residues. Soy protein in supernatant was precipitated by adjusting the supernatant $\mathrm{pH}$ to $\mathrm{pH} 4.8$.

2.4. Differential Scanning Calorimeter (DSC). The denaturation of soy proteins was assessed with a differential scanning calorimeter (DSC) (DSC7, Perkin-Elmer, Norwalk, CT) calibrated with indium and zinc. Wet soy protein samples were hermetically sealed in a large-volume stainless pan. About
$10 \mathrm{mg}$ soy protein $(\mathrm{dmb})$ with moisture around 60\% was loaded. Samples were scanned from 10 to $150^{\circ} \mathrm{C}$ at a heating rate of $10^{\circ} \mathrm{C} / \mathrm{min}$. Denaturation temperatures $\left(T_{d}\right)$ were determined from the peak temperatures. Denaturation enthalpies $(\Delta H)$ were calculated from the areas of the denaturation peaks.

2.5. SDS-PAGE. The precipitated wet protein was diluted with distilled water by adjusting $\mathrm{pH}$ to $\mathrm{pH} 8.2$ using $2 \mathrm{~N} \mathrm{NaOH}$. Protein concentration was determined with Bradford method. SDS-PAGE of soy protein samples was performed on a $4 \%$ stacking gel and $12 \%$ separating gel. Fifty milligrams of soy protein was inoculated into the gel for each sample. A prestained standard with molecular weight from $8 \mathrm{kDa}$ to $250 \mathrm{kDa}$ was used. Electrophoresis was performed at $120 \mathrm{~V}$ for $2 \mathrm{hr}$. The gel was stained in $0.1 \%$ Coomassie brilliant blue R-250 and destained in a solution containing 10\% acetic acid and $40 \%$ methanol. Densitometry of the gel was analyzed by the Kodak 1D Image Analysis software, version 4.6 (Kodak, Rochester, NY).

2.6. Western Blot Procedures with Human Plasma. Western blot was performed according to the method of Frias et al. [5] with modifications. Human plasma used had soybeanspecific IgE $10 \mathrm{kUA} / \mathrm{L}$ provided by PlasmaLab International (Everett, WA). After transferring, the membrane was stained with Ponceau $S$ for 5 min to check the transferring effect. Ponceau $S$ was then washed off with distilled water before proceeding to the next step. For the saturation solution, primary and secondary antibodies were prepared in trisbuffered saline (TBS) instead in $0.01 \%$ Tween in TBS (TTBS) buffer, to avoid the dark background. The membrane was exposed to Kodak X-ray film.

2.7. Chemical Analyses. The proximate composition was analyzed by the Agricultural Experiment Station Chemical Laboratories, University of Missouri (Columbia, MO) using the following methods: crude protein (AOAC Official Method 990.03, 2006) [14], crude fat (ether extraction, AOAC Official Method 920.39 (A)) [14], crude fiber (AOAC Official Method 978.10, 2006) [14], acid detergent fiber (ADF) (AOAC Official Method 973.18 (A-D), 2006) [14], neutral detergent fiber (NDF) [14], cellulose (AOAC Official Method 973.18 (AD), 2006) [14], pepsin digestibility (AOAC Official Method 971.09, 2006) [14], amino acid profile (AOAC Official Method 982.30 E (a, b, c), chp.45.3.05, 2006) [14], and available lysine (AOAC Official Method 975.22, chp.45.4.03, 2006) [14].

\section{Results}

Figure 1 shows the DSC results of soy protein samples pretreated at different temperatures and their corresponding fermentation products. SM and SMV both had two peaks, with the degradation temperatures $\left(T_{d}\right)$ at around $79^{\circ} \mathrm{C}$ and $96^{\circ} \mathrm{C}$. SM100C and SM100 each had one peak at temperature around $97^{\circ} \mathrm{C}$. SM121C and SM121 had one indiscernible peak at around $97^{\circ} \mathrm{C}$. 


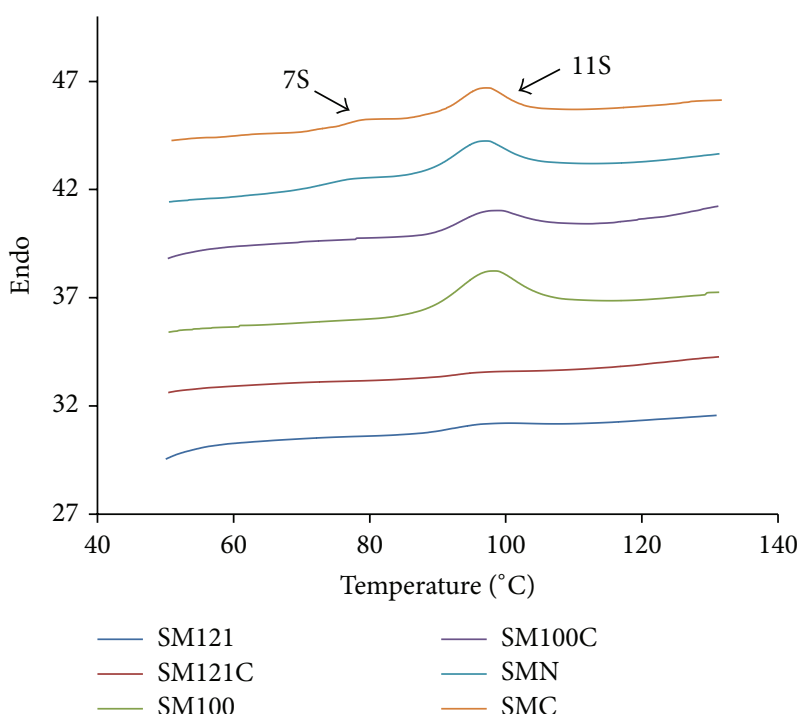

FIGURE 1: DSC thermogram of soy protein and fermented soy protein pretreated at different conditions.

Figure 2 shows the SDS-PAGE results of soy meal samples with different pretreatment. SM contained $79 \%$ bands with molecular weight larger than $60,000 \mathrm{kDa}$, but SM100C only had $4 \%$ bands and SM121C only had $6 \%$ bands in that range. For SMV, SM100, and SM121, the three fermented samples, the molecular weight of all peptides was smaller than $60,000 \mathrm{kDa}$. All the fermented samples had $2 \%$ small peptides with molecular weight smaller than $10,000 \mathrm{kDa}$, which the controlling unfermented samples were not endowed. The $\alpha$ and $\alpha^{\prime}$ subunits of SM were not shown in SMV, and $\beta$ conglycinin was not shown in SM100 and SM121 and their controls.

Figure 3 shows the Ponceau S staining of the membrane after transferring. Comparing with Figure 2, all bands in SDS-PAGE gel had been transferred to the membrane. Figure 4 shows the immunodominant proteins interacting with human plasma $10 \mathrm{kUA} / \mathrm{L}$. SM presented the highest complexity protein profile and plasma immunoreactivity towards $\alpha$ - and $\alpha^{\prime}-(75 \mathrm{kDa})$ and $\beta$ - $(50 \mathrm{kDa})$ conglycinin subunits, P34 fraction, and glycinin basic $(30 \mathrm{kDa})$ and acidic $(22 \mathrm{kDa})$ subunits. Its corresponding fermented sample SMV did not have immunoreactive proteins toward $\alpha$ - and $\alpha^{\prime}-(75 \mathrm{kDa})$ conglycinin subunits. Compared with $\mathrm{SM}$, the immunoreactions signals for $\beta$-conglycinin, P34, and acidic $(22 \mathrm{kDa})$ glycinin subunits were weak for SM100C. There was no visible immunoreactivity for $\beta$-conglycinin in SM100. SM121 and SM121C had immunoreactive protein towards basic $(30 \mathrm{kDa})$ glycinin only.

The composition changes of SM samples are shown in Table 1. Heat treatment did not significantly influence the content of crude protein, crude fat, crude fiber, total ash, and pepsin digestibility but decreased the content of crude fiber, acid detergent fiber, and cellulose content and increased the neutral detergent fiber. Also, heat treatment decreased the content of available lysine content. The higher the temperature, the lower the available lysine content of heat
TABLE 1: Proximates of soy meal samples.

\begin{tabular}{lcccccc}
\hline Samples & SM & SMV & SM100C & SM100 & SM121C & SM121 \\
\hline $\begin{array}{l}\text { Crude } \\
\text { protein }\end{array}$ & $50.46^{\mathrm{b}}$ & $58.78^{\mathrm{a}}$ & $50.74^{\mathrm{b}}$ & $58.82^{\mathrm{a}}$ & $50.62^{\mathrm{b}}$ & $58.47^{\mathrm{a}}$ \\
Crude fat & $2.93^{\mathrm{a}}$ & $3.15^{\mathrm{a}}$ & $2.06^{\mathrm{b}}$ & $3.07^{\mathrm{a}}$ & $2.24^{\mathrm{b}}$ & $2.94^{\mathrm{a}}$ \\
Crude fiber & $3.32^{\mathrm{b}}$ & $4.14^{\mathrm{c}}$ & $3.11^{\mathrm{c}}$ & $4.37^{\mathrm{b}}$ & $3.02^{\mathrm{c}}$ & $5^{\mathrm{a}}$ \\
Ash & $6.68^{\mathrm{d}}$ & $8.05^{\mathrm{b}}$ & $6.93^{\mathrm{c}}$ & $8.24^{\mathrm{a}}$ & $6.66^{\mathrm{d}}$ & $8.31^{\mathrm{a}}$ \\
ADF & $5.48^{\mathrm{c}}$ & $7.7^{\mathrm{a}}$ & $4.74^{\mathrm{c}}$ & $7.52^{\mathrm{a}}$ & $4.67^{\mathrm{c}}$ & $7.11^{\mathrm{b}}$ \\
NDF & $8.18^{\mathrm{b}}$ & $10.13^{\mathrm{b}}$ & $12.38^{\mathrm{b}}$ & $11.41^{\mathrm{b}}$ & $18.15^{\mathrm{a}}$ & $12.3^{\mathrm{b}}$ \\
Cellulose & $5.41^{\mathrm{c}}$ & $7.51^{\mathrm{a}}$ & $4.75^{\mathrm{d}}$ & $7.42^{\mathrm{a}}$ & $4.62^{\mathrm{d}}$ & $6.99^{\mathrm{b}}$ \\
$\begin{array}{l}\text { Pepsin } \\
\text { digestibility }\end{array}$ & $95.33^{\mathrm{a}}$ & $93.07^{\mathrm{c}}$ & $95.18^{\mathrm{a}}$ & $94.1^{\mathrm{b}}$ & $94.84^{\mathrm{a}}$ & $93.33^{\mathrm{c}}$ \\
$\begin{array}{l}\text { Available } \\
\text { lysine }\end{array}$ & $3.06^{\mathrm{b}}$ & $3.07^{\mathrm{b}}$ & $2.95^{\mathrm{c}}$ & $3.08^{\mathrm{b}}$ & $2.84^{\mathrm{d}}$ & $3.26^{\mathrm{a}}$ \\
\hline
\end{tabular}

Mean values in a row with different superscript letters are significantly different according to the least-significant difference (LSD) test at the 0.05 level analyzed by SAS software (2009).

TABLE 2: Amino acids changes of soy protein with different treatment.

\begin{tabular}{|c|c|c|c|c|c|c|}
\hline Sample & SM & SMV & SM100C & SM100 & SM121C & SM121 \\
\hline Hydroxyproline & $0^{\mathrm{b}}$ & $0.11^{\mathrm{a}}$ & $0.1^{\mathrm{a}}$ & $0.11^{\mathrm{a}}$ & $0^{\mathrm{b}}$ & $0.12^{\mathrm{a}}$ \\
\hline Aspartic acid & $5.77^{\mathrm{b}}$ & $6.27^{\mathrm{a}}$ & $5.62^{\mathrm{c}}$ & $6.24^{\mathrm{a}}$ & $5.66^{\mathrm{bc}}$ & $6.3^{\mathrm{a}}$ \\
\hline Threonine & $1.93^{\mathrm{b}}$ & $2.09^{\mathrm{a}}$ & $1.92^{\mathrm{b}}$ & $2.17^{\mathrm{a}}$ & $1.85^{\mathrm{b}}$ & $2.15^{\mathrm{a}}$ \\
\hline Serine & $2.14^{\mathrm{a}}$ & $2.58^{\mathrm{a}}$ & $2.34^{\mathrm{a}}$ & $2.57^{\mathrm{a}}$ & $2.04^{\mathrm{a}}$ & $2.29^{\mathrm{a}}$ \\
\hline Glutamic acid & $8.85^{\mathrm{ab}}$ & $8.91^{\mathrm{ab}}$ & $8.42^{\mathrm{b}}$ & $9.07^{\mathrm{a}}$ & $8.66^{\mathrm{ab}}$ & $9.02^{\mathrm{a}}$ \\
\hline Proline & $2.53^{\mathrm{bc}}$ & $3.04^{\mathrm{a}}$ & $2.45^{\mathrm{c}}$ & $2.62^{\mathrm{bc}}$ & $2.51^{b c}$ & $2.67^{\mathrm{b}}$ \\
\hline ine & $2.14^{\mathrm{b}}$ & $2.28^{\mathrm{a}}$ & $2.05^{\mathrm{b}}$ & $2.38^{\mathrm{a}}$ & $2.07^{\mathrm{b}}$ & $2.39^{\mathrm{a}}$ \\
\hline Alanine & $2.19^{\mathrm{b}}$ & $2.41^{\mathrm{a}}$ & $2.13^{\mathrm{b}}$ & $2.39^{\mathrm{a}}$ & $2.13^{\mathrm{b}}$ & $2.45^{\mathrm{a}}$ \\
\hline Cysteine & $0.7^{\mathrm{b}}$ & $0.8^{\mathrm{a}}$ & $0.66^{\mathrm{b}}$ & $0.82^{\mathrm{a}}$ & $0.67^{\mathrm{b}}$ & $0.82^{\mathrm{a}}$ \\
\hline Valine & $2.52^{\mathrm{d}}$ & $2.96^{\mathrm{ab}}$ & $2.63^{\mathrm{c}}$ & $2.89^{\mathrm{b}}$ & $2.51^{\mathrm{d}}$ & $3.01^{\mathrm{a}}$ \\
\hline Methionine & $0.72^{\mathrm{d}}$ & $0.75^{\mathrm{c}}$ & $0.68^{\mathrm{f}}$ & $0.76^{\mathrm{b}}$ & $0.7^{\mathrm{e}}$ & $0.78^{\mathrm{a}}$ \\
\hline Isoleucine & $2.39^{\mathrm{dc}}$ & $2.52^{\mathrm{b}}$ & $2.32^{\mathrm{d}}$ & $2.47^{\mathrm{bc}}$ & $2.33^{\mathrm{d}}$ & $2.63^{\mathrm{a}}$ \\
\hline Leucine & $3.92^{\mathrm{c}}$ & $4.43^{\mathrm{a}}$ & $3.95^{\mathrm{c}}$ & $4.24^{\mathrm{b}}$ & $3.84^{\mathrm{d}}$ & $4.24^{\mathrm{b}}$ \\
\hline & $1.84^{\mathrm{b}}$ & $1.94^{\mathrm{a}}$ & $1.78^{\mathrm{b}}$ & $1.91^{\mathrm{a}}$ & $1.77^{\mathrm{b}}$ & $1.93^{\mathrm{a}}$ \\
\hline Phenylalanine & $2.53^{b c}$ & $2.75^{\mathrm{a}}$ & $2.48^{\mathrm{c}}$ & $2.58^{\mathrm{b}}$ & $2.48^{\mathrm{c}}$ & $2.59^{\mathrm{b}}$ \\
\hline Hydroxylysine & $0.03^{\mathrm{a}}$ & $0.02^{\mathrm{ab}}$ & $0.01^{\mathrm{c}}$ & $0.02^{\mathrm{ab}}$ & $0.02^{\mathrm{ab}}$ & $0.02^{\mathrm{ab}}$ \\
\hline Ornithine & $0.03^{\mathrm{b}}$ & $0.04^{\mathrm{b}}$ & $0.03^{\mathrm{b}}$ & $0.05^{\mathrm{b}}$ & $0.04^{\mathrm{b}}$ & $0.07^{\mathrm{a}}$ \\
\hline Lysine & $3.24^{\mathrm{b}}$ & $3.22^{\mathrm{b}}$ & $3.12^{\mathrm{c}}$ & $3.29^{\mathrm{b}}$ & $3.1^{\mathrm{c}}$ & $3.51^{\mathrm{a}}$ \\
\hline Histidine & $1.32^{\mathrm{b}}$ & $1.38^{\mathrm{a}}$ & $1.27^{\mathrm{c}}$ & $1.37^{\mathrm{a}}$ & $1.27^{\mathrm{c}}$ & $1.4^{\mathrm{a}}$ \\
\hline Arginine & $3.64^{\mathrm{a}}$ & $3.48^{\mathrm{c}}$ & $3.56^{\mathrm{b}}$ & $3.48^{\mathrm{c}}$ & $3.52^{\mathrm{bc}}$ & $3.57^{\mathrm{b}}$ \\
\hline Tryptophan & $0.74^{\mathrm{c}}$ & $0.81^{\mathrm{b}}$ & $0.79^{\mathrm{b}}$ & $0.89^{\mathrm{a}}$ & $0.71^{\mathrm{c}}$ & $0.92^{\mathrm{a}}$ \\
\hline Total & $49.13^{\mathrm{b}}$ & $52.73^{\mathrm{a}}$ & $48.28^{\mathrm{b}}$ & $52.27^{\mathrm{a}}$ & $47.84^{\mathrm{b}}$ & $52.83^{\mathrm{a}}$ \\
\hline
\end{tabular}

Mean values in a row with different superscript letters are significantly different according to the least-significant difference (LSD) test at the 0.05 level analyzed by SAS software (2009).

pretreated soy meal. The content of all components increased after fermentation, except for the fact that pepsin digestibility decreased. Fermented samples with higher heat treatment had higher available lysine.

Amino acid contents of fermented samples are shown in Table 2. Heat treatment did not significantly affect essential amino acids content, except for lysine. Fermentation 


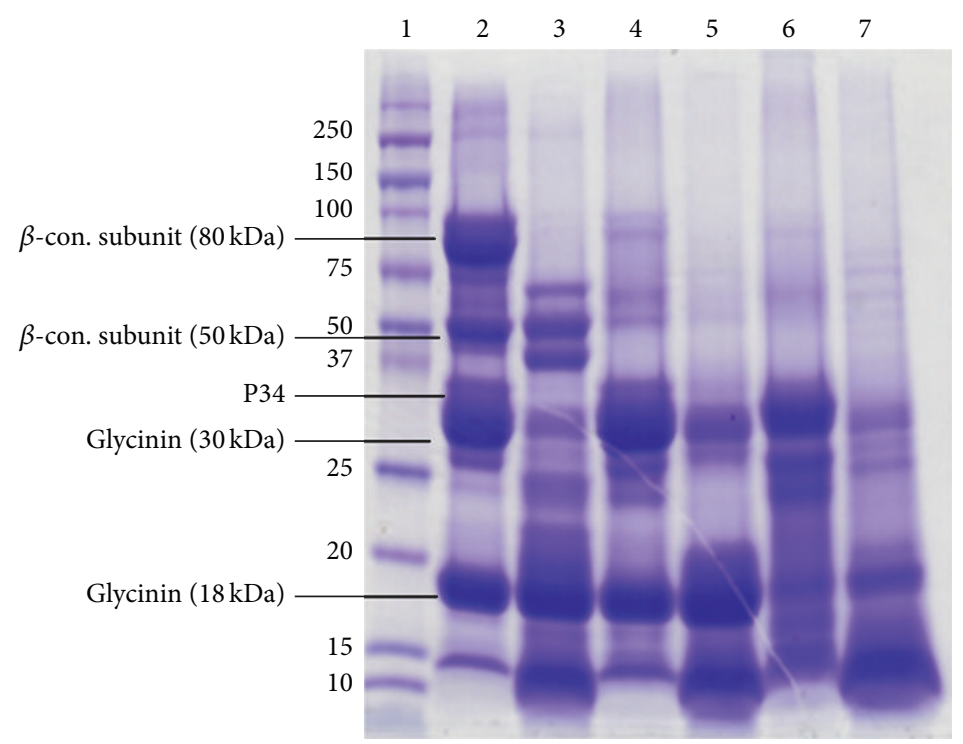

FIGURE 2: SDS-PAGE for soy protein and fermented soy protein pretreated at different conditions. Lane 1: prestained standard; lane 2: SM; lane 3: SMV; lane 4: SM100C; lane 5: SM100; lane 6: SM121C; lane 7: SM121.

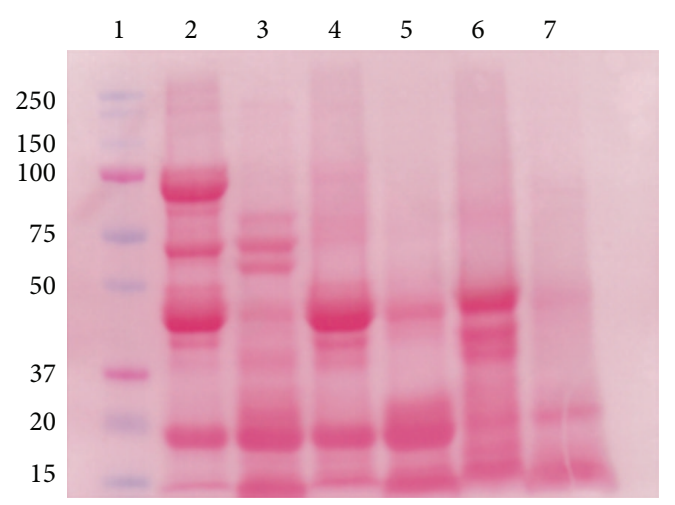

Figure 3: Ponceau S staining of the membrane after transferring. Lane 1: prestained standard; lane 2: SM; lane 3: SMV; lane 4: SM100C; lane 5: SM100; lane 6: SM121C; lane 7: SM121.

increased the total amino acids content of SM, SM100C, and SM121C by $7 \%, 8 \%$, and $9 \%$, respectively. Fermentation also increased all amino acids contents. The higher the temperature, the higher the amino acid content of fermented samples. Methionine, cysteine, and threonine in SM121 increased by $11.4 \%, 22.39 \%$, and $16.22 \%$ after fermentation, respectively. Lysine and tryptophan in SM121 increased by $13 \%$ and 30\% compared with SM121C.

\section{Discussion}

Soy protein denaturation is an endothermic process [15], caused by rupture of inter- and intramolecular bonds. Its denaturation degree could be shown by DSC. Undenatured soy protein has two peaks in the DSC curve, which represent the two main soy storage proteins, conglycinin and glycinin [15]. Glycinin is more heat stable than conglycinin [15]. The $T_{d}$ for glycinin was in the range of $96.3-97.7^{\circ} \mathrm{C}$, while the $T_{d}$ for conglycinin was in the range of $77.1-79.3^{\circ} \mathrm{C}$ (Figure 1). Protein denaturation is a nonreversible process [15]. The denatured protein would not show peaks on the DSC diagram. According to Figure 1, protein in SM and SMV was nondenatured; $7 S$ subunits in SM100C and SM100 were denatured; in SM121C and SM121, 7S subunits were totally denatured while $11 \mathrm{~S}$ subunits were almost totally denatured.

SDS-PAGE is a common method to evaluate protein molecular size. But for heat treated samples, it did not work well, according to our result. The denatured $7 \mathrm{~S}$ subunit of soy protein was not shown on SM100C and SM121C lanes. This did not mean that SM100C and SM121C had less large molecular weight protein. Protein denaturation was the change of the secondary, tertiary, and quaternary structures. Thermal energy input disrupted the weak bonds stabilizing the native conformation, causing protein to unfold [16]. The denatured protein may form large aggregate [17], which may become insoluble and would not be shown on SDS-PAGE. Wang et al. [16] also showed that $100^{\circ} \mathrm{C}$ heating for $20 \mathrm{~min}$ resulted in the loss of protein bands on SDS gel. The addition of virginiamycin avoided the heat pretreatment of soy meal. A. oryzae solid state fermentation could degrade large protein molecules into smaller peptides, as shown by comparing the molecular weight of SM and SMV from Figure 2.

About 34 subunits of soy protein have been recognized as allergens [3]. Our result also showed the strong signal of immunoreactive protein in SM. Heat treatment has been shown to affect allergen conformational epitopes and decrease its immunoreactivity [18]. Western blot has been used to illustrate protein immunoreactivity. Like SDS-PAGE, there was still the problem caused by heat induced protein 


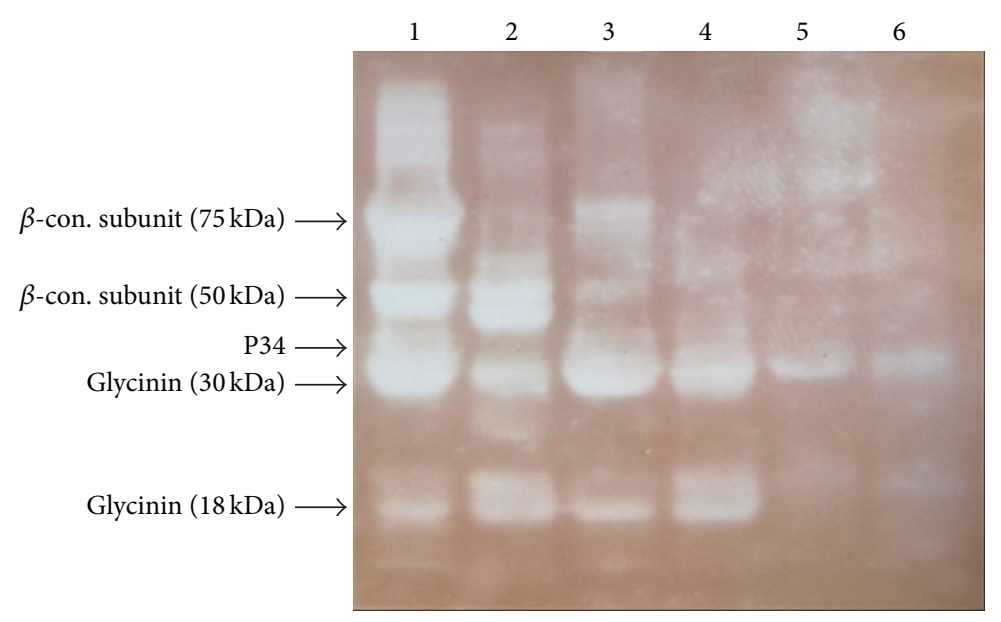

FIGURE 4: Western blot results of soy protein samples. Lane 1: SM; lane 2: SMV; lane 3: SM100C; lane 4: SM100; lane 5: SM121C; lane 6: SM121.

denature. Subunits of soy protein, like $\beta$-conglycinin in SM100C and SM121C and acidic glycinin in SM121C, were not visible on western blot. This did not mean that they did not have immunoreactivity, but they were not present on SDS gel. The virginiamycin addition helped investigate soy protein immunoreactivity change during fermentation process. The weaker immunoreactive signals for SMV, comparing with SM, illustrated that $A$. oryzae solid state fermentation could decrease immunoreactive soy protein.

Natural fermentation has been shown to degrade soy protein molecular size with nonheated samples [5]. In the natural fermentation, various kinds of microorganisms have been involved. Different proteases target different protein subunits [19]. In order to achieve better degradation, it is necessary to investigate the fermentation effect of specific microorganism. Virginiamycin could inhibit bacterial growth while the inoculum of desired fungus could inhibit the growth of other contaminating fungi, according to our results. Virginiamycin addition excluded the necessity of heat treatment, which was beneficial to the protein size and immunoreactivity investigation.

$A$. oryzae secretes acidic and neutral proteases, which could degrade epitopes [18]. According to our research, $A$. oryzae fermentation provides means to degrade soy protein molecular size while decreasing its immunoreactive protein. Soy protein with low molecular weight and weak or no immunoreactive protein have been added to newly weaned piglets' diet to lower the feeding cost [2]. Fermentation parameters, such as temperature, moisture, and fermentation time, need to be optimized to maximize the protein degradation and to produce hypoallergenic fermented soy products for young pigs.

Acid detergent fiber mainly includes cellulose and lignin. Neutral detergent fiber mainly includes hemicelluloses, cellulose, and lignin. Heat treatment may degrade lignin or catalyze complex structure formation between hemicelluloses and lignin or hemicelluloses with other components, like lysine. Lysine is susceptible to react with other compounds, such as reducing sugars to form Maillard compounds, resulting in the loss of available lysine and reduction of nutritional value. A. oryzae secretes various kinds of enzymes, such as $\alpha$-amylase, carboxymethyl cellulase, pectin lyase, protease, and endo- $\beta$-xylanase (EC 3.2.1.8) [20] to help utilize soy meal components to meet its growth needs. The enhancement of all components by fermentation was mainly because of the dry matter loss resulting from $A$. oryzae consumption, which concentrated the nutritional compounds. Proper heat could unfold protein structure and make protein easier to digest by proteases. The decrease of the pepsin digestibility may be partially contributed by the increased protein content.

Soy protein is rich in lysine and tryptophan but lacking in methionine and threonine, compared with cereals proteins. SM and maize are main ingredients for monogastric animals' diet and provide complementary amino acid profiles. Amino acids deficiency may decrease feed efficiency and feed intake, cause weight loss, and influence animals' growth performance [21]. A. oryzae solid state fermentation enhanced the amino acid contents of all samples, especially for the SM121. One reason for the increase of amino acids is the dry matter loss, which has been illustrated for solid state fermentation [22]. The second reason is the hydrolysis of protein by protease secreted from $A$. oryzae [22]. Also, the increase of $A$. oryzae biomass contributes to the amino acids and protein increase [22]. Heat treatment could expose inside peptide bonds and ease enzymatic hydrolysis. Proper heat treatment might benefit the subsequent fermentation process.

A. oryzae solid state fermentation could degrade large soy protein molecular size and decrease soy protein immunoreactivity. A. oryzae protease had priority for $\alpha$ and $\alpha^{\prime}$ components of $\beta$-conglycinin. Virginiamycin facilitated the investigation on fermentation degradation of soy protein, by avoiding the interruption from heating. Fermentation enhanced the nutritional value of soy meal, with higher protein content. Essential amino acids contents were also enhanced by fermentation. Proper heat treatment facilitated the fermentation process. The value added FSM should have a wider market than SM, particularly for newly weaned piglets. 


\section{Abbreviations}

ATCC: American Type Culture Collection

DSC: Differential scanning calorimetry

SDS-PAGE: Sodium dodecyl sulfate polyacrylamide gel electrophoresis

ADF: $\quad$ Acid detergent fiber

NDF: $\quad$ Neutral detergent fiber

AOAC: Association of Official Analytical Chemists

SM: $\quad$ Soy meal

FSM: $\quad$ Fermented soy meal

SMV: $\quad$ Fermented soy meal with virginiamycin added

SM100C: $\quad$ Soy meal autoclaved at $100^{\circ} \mathrm{C}$ for $30 \mathrm{~min}$

SM100: $\quad$ Fermented soy meal which was autoclaved at $100^{\circ} \mathrm{C}$ for $30 \mathrm{~min}$

SM121C: $\quad$ Soy meal autoclaved at $121^{\circ} \mathrm{C}$ for $15 \mathrm{~min}$

SM121: $\quad$ Fermented soy meal which was autoclaved at $121^{\circ} \mathrm{C}$ for $15 \mathrm{~min}$.

\section{Conflict of Interests}

The authors declare that there is no conflict of interests regarding the publication of this paper.

\section{Acknowledgments}

The authors would like to thank Dr. Timothy Durrett in the Department of Biochemistry, Kansas State University, for helping with the western blot analysis. The authors are grateful to the Department of Grain Science and Industry, Kansas State University, and Kansas Soybean Commission for funding this project. This is Contribution no. 13-155-J from the Kansas Agricultural Experiment Station.

\section{References}

[1] L. Chen, Y. Zhang, R. L. Madl, and P. V. Vadlani, "Nutritional enhancement of soybean meal and hull via enzymatic and microbial bioconversion," in Soybeans: Cultivation, Uses and Nutrition, J. E. Maxwell, Ed., Nova Science Publishers, New York, NY, USA, 2010.

[2] Y. S. Song, V. G. Pérez, J. E. Pettigrew, C. Martinez-Villaluenga, and E. G. de Mejia, "Fermentation of soybean meal and its inclusion in diets for newly weaned pigs reduced diarrhea and measures of immunoreactivity in the plasma," Animal Feed Science and Technology, vol. 159, no. 1-2, pp. 41-49, 2010.

[3] S. Wilson, C. Martinez-Villaluenga, and E. G. de Mejia, "Purification, thermal stability, and antigenicity of the immunodominant soybean allergen P34 in soy cultivars, ingredients, and products," Journal of Food Science, vol. 73, no. 6, pp. T106-T114, 2008.

[4] Y. Zhao, G. Qin, Z. Sun et al., "Disappearance of immunoreactive glycinin and $\beta$-conglycinin in the digestive tract of piglets," Archives of Animal Nutrition, vol. 62, no. 4, pp. 322-330, 2008.

[5] J. Frias, Y. S. Young, C. Martínez-Villaluenga, E. G. De Mejia, and C. Vidal-Valverde, "Immunoreactivity and amino acid content of fermented soybean products," Journal of Agricultural and Food Chemistry, vol. 56, no. 1, pp. 99-105, 2008.
[6] Y.-S. Song, J. Frias, C. Martinez-Villaluenga, C. VidalValdeverde, and E. G. de Mejia, "Immunoreactivity reduction of soybean meal by fermentation, effect on amino acid composition and antigenicity of commercial soy products," Food Chemistry, vol. 108, no. 2, pp. 571-581, 2008.

[7] P. Amnuaycheewa and E. G. de Mejia, "Purification, characterisation, and quantification of the soy allergen profilin (Gly $\mathrm{m} \mathrm{3}$ ) in soy products," Food Chemistry, vol. 119, no. 4, pp. 1671-1680, 2010.

[8] E. N. C. Mills, J. A. Jenkins, M. J. C. Alcocer, and P. R. Shewry, "Structural, biological, and evolutionary relationships of plant food allergens sensitizing via the gastrointestinal tract," Critical Reviews in Food Science and Nutrition, vol. 44, no. 5, pp. 379407, 2004.

[9] L. Chen, P. V. Vadlani, and R. L. Madl, "High-efficiency removal of phytic acid in soy meal using two-stage temperatureinduced Aspergillus oryzae solid-state fermentation," Journal of the Science of Food and Agriculture, vol. 94, no. 1, pp. 113-118, 2014.

[10] X. Liu, J. Feng, Z. Xu, Y. Lu, and Y. Liu, "The effects of fermented soybean meal on growth performance and immune characteristics in weaned piglets," Turkish Journal of Veterinary and Animal Sciences, vol. 31, no. 5, pp. 341-345, 2007.

[11] R. Yamanishi, H. Tsuji, N. Bando et al., "Reduction of the allergenicity of soybean by treatment with proteases," Journal of Nutritional Science and Vitaminology, vol. 42, no. 6, pp. 581-587, 1996.

[12] T. J. Dumonceaux, J. E. Hill, S. M. Hemmingsen, and A. G. Van Kessel, "Characterization of intestinal microbiota and response to dietary virginiamycin supplementation in the broiler chicken," Applied and Environmental Microbiology, vol. 72, no. 4, pp. 2815-2823, 2006.

[13] S. H. Hynes, D. M. Kjarsgaard, K. C. Thomas, and W. M. Ingledew, "Use of virginiamycin to control the growth of lactic acid bacteria during alcohol fermentation," Journal of Industrial Microbiology and Biotechnology, vol. 18, no. 4, pp. 284-291, 1997.

[14] AOAC International, Official Methods of Analysis of AOAC International, AOAC International, Gaithersburg, Md, USA, 2006.

[15] R. P. Wool and X. S. Sun, “Thermal and mechanical properties of soy proteins," in Biobased Polymers and Composites, R. P. Wool and X. S. Sun, Eds., pp. 292-300, Elsevier Science Publishers, Boston, Mass, USA, 2005.

[16] Y. Wang, X. S. Sun, and D. Wang, "Effects of preheating treatment on thermal property and adhesion performance of soy protein isolates," Journal of Adhesion Science and Technology, vol. 21, no. 15, pp. 1469-1481, 2007.

[17] S. Utsumi, S. Damodaran, and J. E. Kinsella, "Heat-induced interactions between soybean proteins: preferential association of $11 \mathrm{~S}$ basic subunits and $\beta$ subunits of 7S," Journal of Agricultural and Food Chemistry, vol. 32, no. 6, pp. 1406-1412, 1984.

[18] J. Maldonado, A. Gil, E. Narbona, and J. A. Molina, "Special formulas in infant nutrition: a review," Early Human Development, vol. 53, pp. S23-S32, 1998.

[19] K. Tsumura, "Improvement of the physicochemical properties of soybean proteins by enzymatic hydrolysis," Food Science and Technology Research, vol. 15, no. 4, pp. 381-388, 2009.

[20] L. Chen, R. L. Madl, and P. V. Vadlani, "Value added products from soybean: removal of anti-nutritional factors via bioprocessing," in Soybean: A Review, H. El-Shemy, Ed., pp. 161-179, InTech, 2013. 
[21] S. Moehn, P. B. Pencharz, and R. O. Ball, "Lessons learned regarding symptoms of tryptophan deficiency and excess from animal requirement studies," Journal of Nutrition, vol. 142, no. 12, pp. 2231S-2235S, 2012.

[22] L. Chen, R. L. Madl, and P. V. Vadlani, "Nutritional enhancement of soy meal via Aspergillus oryzae solid-state fermentation," Cereal Chemistry, vol. 90, no. 6, pp. 529-534, 2013. 

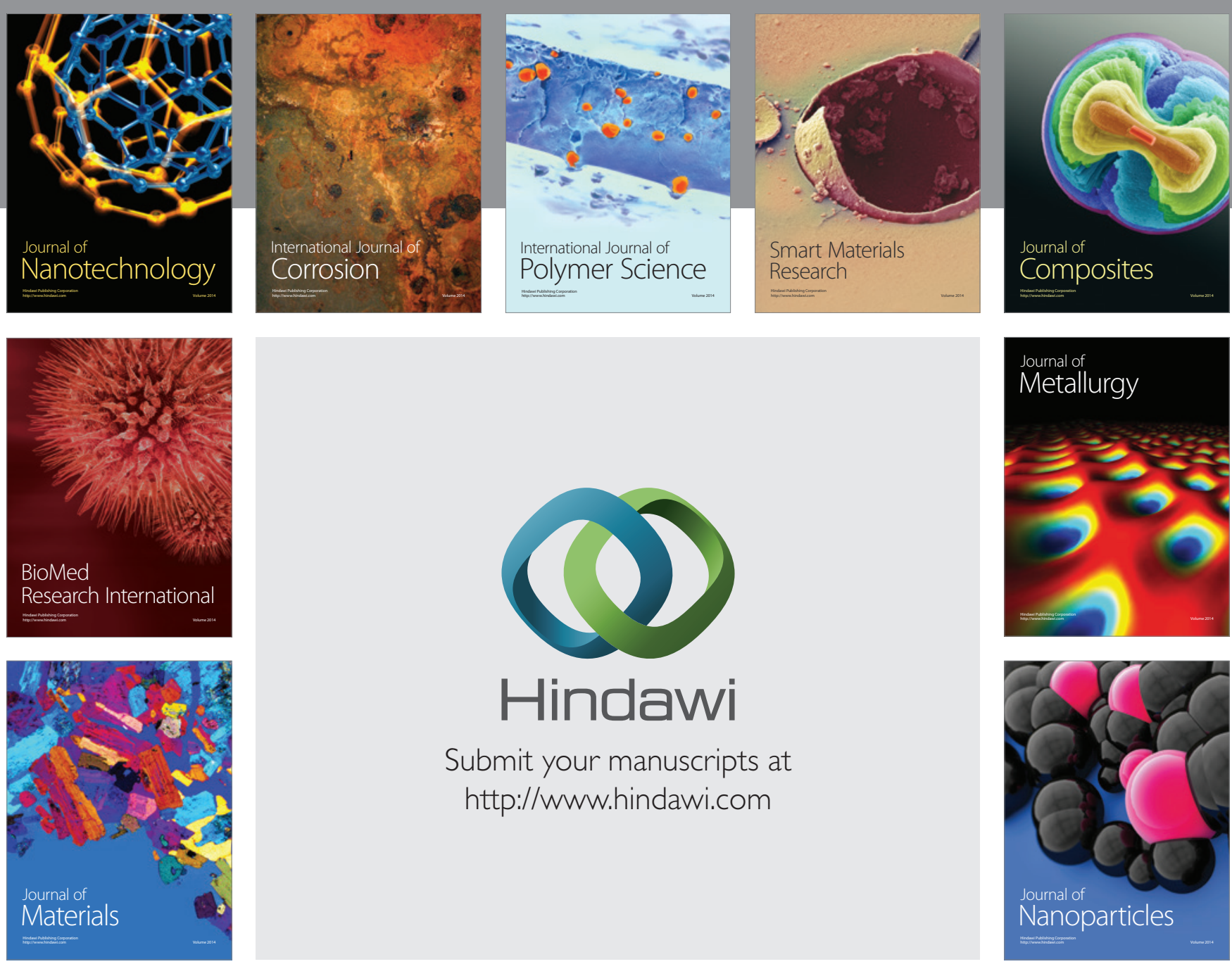

Submit your manuscripts at http://www.hindawi.com
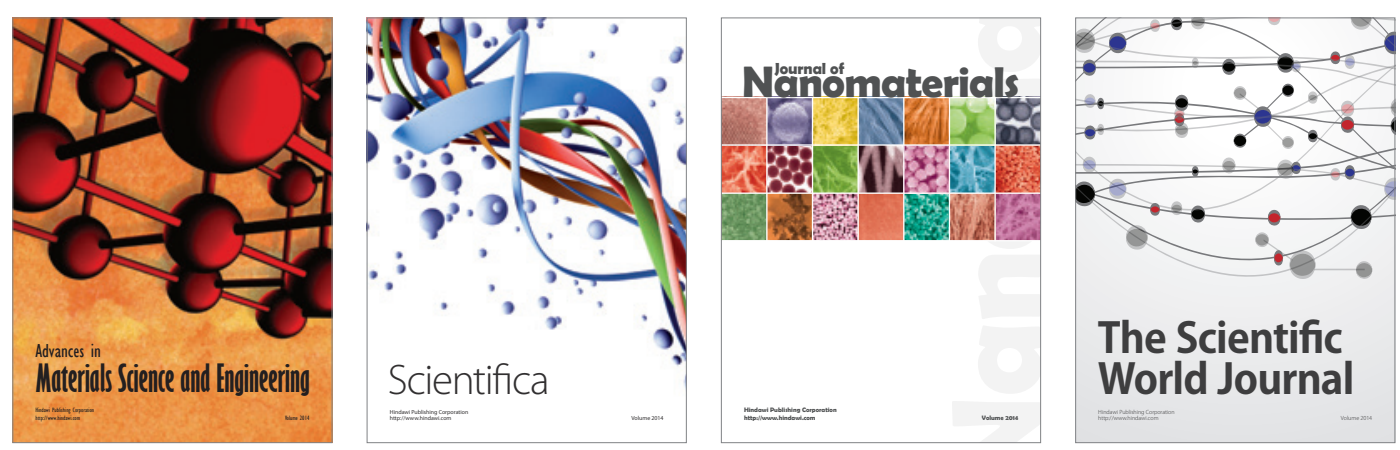

\section{The Scientific World Journal}
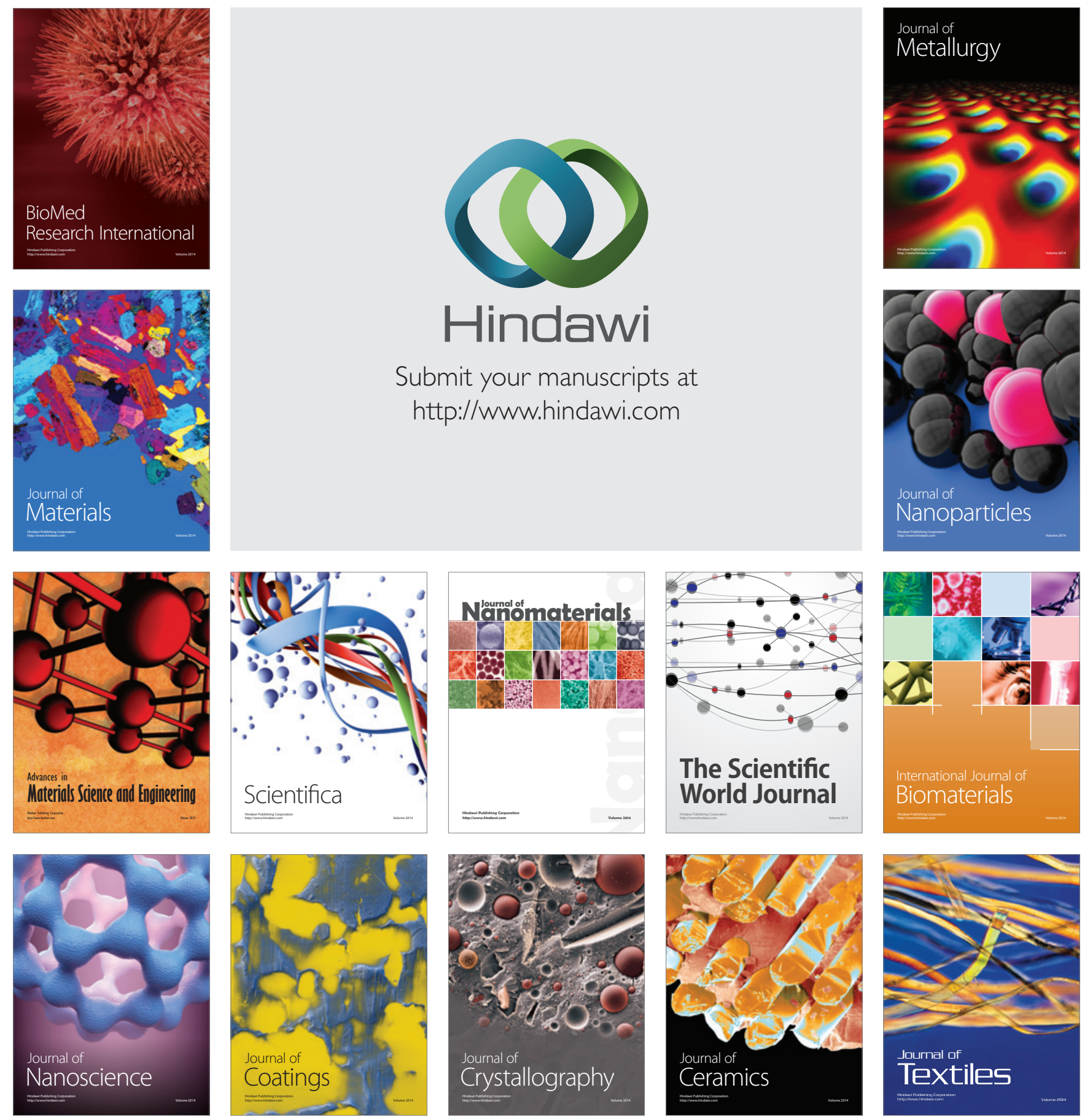